\title{
On the Politeness Strategies in Chinese Internet Relay Chat Communication
}

\author{
Jing Deng1,2 \\ ${ }^{1}$ College of Foreign Languages and Literatures, Fudan University, Shanghai, China \\ ${ }^{2}$ School of Foreign Studies, Nanjing University of Science and Technology, Nanjing, China \\ Email: dengjingchina2005@aliyun.com
}

Received 1 July 2016; accepted 30 July 2016; published 3 August 2016

Copyright (c) 2016 by author and Scientific Research Publishing Inc.

This work is licensed under the Creative Commons Attribution International License (CC BY). http://creativecommons.org/licenses/by/4.0/

(c) (1) Open Access

\begin{abstract}
As a prevalent synchronous form of CMC communication, internet relay chat (IRC) is a major mode of real-time CMC communication in today's Chinese society. Under the framework of Brown and Levinson's face theory, this study investigated the politeness strategies in public Chinese QQ chat groups where most of the interlocutors were anonymous with high social distance. Politeness strategies in public Chinese $Q Q$ chat groups include positive politeness strategy, negative politeness strategy, bald-on-record and off-record strategy.
\end{abstract}

\section{Keywords}

Politeness Strategies, Anonymous, QQ, Chinese Internet Relay Chat, Face Theory, Computer-Mediated Communication

\section{Introduction}

Computer-mediated communication (CMC) is the communication produced when humans interact with one another by transmitting messages via networked computers (Herring, 1996) including electronic mails (e-mail), Internet relay chat (IRC), bulletin board systems (BBS), video conferencing, etc. The language used in CMC communication (c.f. Netspeak (Crystal, 2006)) is different from face-to-face interaction which makes use of both linguistic and paralinguistic cues. There are many studies conducted in different aspects of CMC language among which studies focusing explicitly on pragmatic aspect are a more recent phenomenon, epitomizing the academic shift away from an excessive focus on the influence of the computer medium on communication to focus on user variation within that medium (Lorenzo-Dus et al., 2011).

As a prevalent synchronous form of CMC communication, Internet Relay Chat (IRC) provides a means for users to text real-time messages in chat groups which are virtual communities (Rheingold, 1993) where people 
with similar interests and hobbies can congregate to engage in discussions on a wide variety of topics on computer screen. In IRC communication, the interlocutors are supposed to conform to a set of core rules indicating what should or should not be done in online communication to ensure common courtesy (Shea, 1994). This paper aims to examine the politeness strategies in the popular public Chinese QQ chat groups to shed light on the peculiarity of politeness in CMC context compared with face-to-face communication under the framework of Brown and Levinson's face theory. Exploring the socio-emotional aspects (face) of CMC interaction could provide insights into establishment and maintenance of social relationships through CMC channels. As Al-Shalawi (2001) puts it, a study of computer-mediated communication "can provide us with a crucial direction leading to the understanding of how the principles of social relationships are realized in a new form of language”.

\section{Politeness Strategies in CMC Communication}

The concept of politeness refers to rule-governed strategies through which interpersonal relationship and harmony can be achieved and maintained (Lakoff, 1973; Brown \& Levinson, 1987). Politeness is closely related to face referring to emotional and social sense that needs to be recognized by others (Yule, 2002). Face-work plays the central role in interlocutors' constructing of their discourses and realizes the interpersonal function of avoiding or reducing social friction by protecting their face. Studies on politeness in CMC communication have found that face-threatening acts (FTAs) are unavoidable in CMC communication no less than in face-to-face setting (Hiemstra, 1982; Morand \& Ocker, 2003) and there is evidence for different ways participants adjust their verbal and nonverbal practices when dealing with face management issues to suit the particular condition of the medium (Taleghani-Nikazm, 2013).

Although politeness in CMC context is one of the earliest and most important issues triggering researchers' concern as it is in naturally occurring face-to-face settings, there are few studies focusing on the politeness strategies in public IRC communication where most of the interactants are anonymous strangers with high social distance. Tanskanen's (1998) study examined politeness strategies used in a mailing list discussion group, concluding that many spoken language strategies were also found in the discussion group, including the use of hedges, stance markers and third person pronouns. Pariera (2006) investigated the politeness strategies in Email discussion group about taboo topics and found that email is developing a unique set of politeness strategies different than those used in face-to-face communication. Park (2008) analyzed the pragmatic tactics employed in a synchronous online discussion forum dealing with mathematics. In addition most of the studies on politeness strategies in CMC context are based on western cultures and there is lack of studies in other languages and cultures. Therefore this study is attempted to delineate politeness strategies in public Chinese internet relay chat under the framework of Brown and Levinson's face theory to contribute to the understanding of politeness in non-western languages and cultures in response to calls for more studies in other cultural settings (Herring, 2010).

\section{Brown and Levinson's Face Theory}

Among all the approaches to politeness in interaction, Brown and Levinson's face theory is probably the most influential and widely used politeness theories and it is the framework that will be applied to this study. Brown and Levinson's concept of face is based on the definition given by Goffman which is the public image of the interactant. The concept of face, as in losing or saving face, can be seen as positive social value that one can claim during a particular social interaction (Goffman, 1967). Brown and Levinson (1987) went further to propose that each rational member of society has his own face which can be divided into negative face and positive face. The former means that people have the freedom of action without interference while the latter means that the desire to be approved or the positive individual image to be praised.

Brown and Levinson argued that our need to support each other's face is most salient when taking part in a face threatening act (FTA). These are speech acts that inherently threaten the face wants of either the speaker or hearer. A principal idea behind the FTA is that speakers will try to minimize the threat in order to maintain each other's faces. One way to do this is to use negative politeness strategies or positive politeness strategies. These are redressive actions, defined by Brown and Levinson as those which "attempt to counteract the potential face damage of the FTA by doing it in such a way ... that indicates clearly that no such face threat is intended or desired" (p. 70).

Brown and Levinson thus proposed a model of politeness strategies including four types of politeness strate- 
gies: bald-on record, off-record, positive and negative politeness strategies. Bald-on-record is direct, concise, clear, and unambiguous without linguistic device for mitigation to lessen the force of the speech act involved. The off-record strategy is the most indirect speech act in the sense that the speaker gives full option to the hearer to ignore any speech acts from the speaker. In so doing, the hearer has freedom from imposition without losing face. The positive politeness strategy attends to the hearer's positive face desire while the negative politeness strategy attends to the hearer's negative face desire.

\section{Politeness Strategies in Public Chinese QQ Chat Groups}

All the data of this study was collected from Chinese QQ chat groups which are the most popular free instant messaging (IM) computer programs in Mainland China. And the data for this study comes from the public QQ chat groups since there are not ethics and privacy issues involved. The examples in this study cover a broad range of topics including book reading, making friends, traveling, public welfare, etc. In this section the politeness strategies of Chinese public chat groups will be examined under the framework of Brown and Levinson's face theory.

\subsection{Positive Politeness Strategies}

Positive politeness strategies are intended to avoid giving offense to interlocutors' face by fostering closeness, solidarity and cohesion. In IRC communication most interlocutors are physically isolated and visually anonymous; therefore, positive politeness strategies are frequently adopted to cater to both the speaker and the hearer's positive face want and thus helps to create a highly sociable environment. The main positive strategies in public Chinese QQ chat groups include using solidarity in-group identity markers, asserting common ground, including both speaker and hearer in activity, avoiding disagreement and complimenting.

\subsubsection{Use Solidarity in-Group Identity Markers}

Positive face desire is closely linked with solidarity, involvement and proximity with others (Scollon \& Scollon, 1983) which is expressed by using in-group terms such as a nickname (i.e., Jake), an endearment term (i.e., honey), or acknowledgement (i.e., thanks). In IRC communication the interlocutors are mostly strangers and these in-group terms make them feel that they belong to the same group and thus contributes to increasing social proximity and solidarity among the interlocutors and enhancing positive interpersonal relationships and atmosphere.

Example 1 S: 有中秋节生日的小伙伴吗? 求认识呢, 我是九八年的

$\mathrm{H}$ : 咱俩同一天呢

(S: Is there any little buddy with their birthdays on the day of Mid-autumn Festival?

Could we get to know each other? I'm born in 1998.)

(H: We two are born on the same day.)

Example 1 comes from a friend-making chat group where most members are born in the 90s and at their young age. The speaker would like to get acquainted with other members of the group by resorting to their age identity marker "xiăohuǒbàn" which is frequently used online among teenagers or young people for friendliness and solidarity ("xiăo" in Chinese means "little, young" and "huǒbàn" is an unspecified address term for "friend"). The hearer then answered with the subject "zánliăng" (we two), an addressivity including both the speaker and hearer, suggesting that their social distance was shortened and the hearer's positive face need is attended to.

\subsubsection{Assert Common Ground}

Common ground includes shared or mutual knowledge, assumptions and beliefs (Stalnaker, 1978). In IRC communication, most of the interlocutors are unfamiliar and their frequent activity is the establishment, and subsequent refinement, of common ground (Clark, 1992) which facilitates the progression of the conversation and establishment of relationships.

\section{Example 2 S: 大家都选择的哪家留学中介呢?}


H: 你好。我也是留学生, 私信你啦
(S: Which overseas study agency do all of you choose?)
(H: Hello, I'm an overseas student too. I've send you private messages.)

In the above example, the speaker was trying to seek advice in the chat group for selecting overseas study agencies responsible for his study abroad. The hearer established their common ground by mentioning their identity of overseas students ("liúxuéshēng", overseas student) with the implication that he was qualified as an advice-giver with experience in this aspect. Claiming the common feature between them alleviated the speaker's positive face and made it possible for the hearer to send private messages to the speaker after he ceased to give further details due to the publicity of relay chat.

\title{
4.1.3. Include Both Speaker and Hearer in the Activity
}

By including speaker and hearer in the same activity, the speaker intends to create casual and intimate social contexts. In IRC communication the speaker may draw upon "in-group" speech forms, i.e. linguistic elements characteristic of speech among social intimates (Joos, 1962; Ervin-Tripp, 1972) to involve both sides in the same action.

\author{
Example 3 S: 简单介绍一下个人情况: 98 年/金牛座/文科重点班 \\ 年级大概有文科生 250 人左右 \\ 目前最高的排名在 60 名 \\ $\mathrm{H}$ : 我是内蒙的, 同文科...高一的, 学姐加油 \\ S: 你好呀一起加油呀 \\ (S: Here is a brief introduction of mine: \\ Born in 1998/Taurus/key class of liberal arts; \\ Until now my highest school ranking is 60 among about 250 students in my grade.) \\ (H: I'm from Inner Mongolia Province and in class of liberal arts too. \\ I'm in senior grade one. Go for it, senior!) \\ (S: Hello, let's go for it together!)
}

Example 3 is from the QQ chat group focusing on preparation for Chinese college matriculation examination where the speaker was introducing his academic performance. After the hearer responded with encouragement, the speaker echoed by including them in the concerted efforts for the exam which is considered as severe competition for all candidates. Here the use of the imperative (yìqŭ, "let's") placed both the speaker and hearer in the same role with similar outlooks and goals to foster an air of cooperation and thus enhance the positive face of the hearer.

\subsubsection{Avoid Disagreement}

For Brown \& Levinson (1987: p. 66), disagreements are positive-face threatening acts because the speaker conveys to the addressee that he or she is wrong, misguided or unreasonable about an issue, thus revealing a lack of concern for that person's feelings and/or wants. To redress such threat, Brown \& Levinson (1987: pp. 112-113) propose the positive politeness strategy "avoid disagreement”. Likewise, Leech (1983) identifies "a tendency to exaggerate agreement with other people, and to mitigate disagreement”.

Example 4 S: 考研不是最终目的, 每个人选择不同, 最终目的都是为了工作和生计, 你千万不要 认为考上研究生就会怎样, 出来和本科生一样找工作

$\mathrm{H}$ : 呵阿

S: 别呵呵, 哥是过来人, 首都医科大学神外科

$\mathrm{H}$ : 恩, 支持你。

(S: Passing the postgraduate entrance exam is not the ultimate goal. Everyone has different options, but the final aim is always for work and livelihood. Never think that becoming a postgraduate student can give you an edge in the job market. You need to try hard to find a good job when you finish school as the undergraduates do.)

(H: Hehe) 
(S: Don't hehe. I've gone through it all. I'm postgraduate of neurosurgery, Capital Medical University in Beijing.)

(H: Yep, I'm on your side.)

In the above example, the speaker and hearer were discussing about the advantage of upgrading one's education to become postgraduate students in China. When the speaker mentioned postgraduate students' risk of securing a good job as that of students with bachelor's degrees, the hearer responded with Chinese onomatopoeia word "hehe". Hehe is frequently used in Chinese CMC communication imitative of humans' sound of smile to show gentility and warmth since there is a lack of paralinguistic information of prosody, kinesics, instant feedback, etc. in CMC settings, normally a primary factor in face-to-face interaction. Here, hehe serves as mitigator of the hearer's unconcern and carelessness or even a slight disapproval of the speaker's opinion to cater to the speaker's positive face want.

\subsubsection{Compliment}

In Austin's Speech Act Theory (1962), compliment appears in classification under the class of "behabitives" as a means of expressing sympathy along with congratulations, condolences and felicitations more specifically. Wierzbicka (1991: p. 87) remarks that compliments are usually intended to make others feel good and are performed for maintaining good interpersonal relationships.

\section{Example 5 S: 上半年的时候辞了工作, 开始一场说走就走的旅行。 穷不是一种状态, 而是一种心态 \\ $\mathrm{H}$ : 你现在做什么工作了哥们儿? 很欣赏你 \\ (S: I resigned in the first half of the year and went on a trip decided on a whim. Poverty is not a state of living but that of mentality.) \\ (H: What are you doing now for living, buddy? I really admire you.)}

In the above example, the speaker mentioned his resignation from job and completed a trip he craved for. Then the hearer showed interest in his life and enquired about his present job. By complimenting on the speaker's determination and courage the hearer shortened the social distance between them and softened the face threat to the speaker when he asked about his present job which is considered as infringement of privacy.

\subsection{Negative Politeness Strategies}

Negative politeness strategies are oriented towards the hearer's negative face and emphasize avoidance of imposition on the hearer. The chief negative politeness strategies in Chinese IRC communication include being conventionally indirect, minimizing the imposition, showing deference, being pessimistic and stating the general rule.

\subsubsection{Be Conventionally Indirect}

The notions of indirectness and politeness play a crucial role in the negotiation of face during the realization of speech acts such as requests. According to Brown \& Levinson (1987) and Leech (1983) higher levels of indirectness may result in higher levels of politeness. And Blum-Kulka (1989) held that indirectness is comprised of two types: conventional indirectness which centers on conventions of language including propositional content (literal meaning) and pragmalinguistic form used to signal an illocutionary force, and nonconventional indirectness which relies heavily on the context and tends to be "open ended, both in terms of propositional content and linguistic form as well as pragmatic force” (1989: 42).
Example 6
S: 各位好心人, 能救救我的父亲吗?
$\mathrm{H}$ : 加油, 你爸爸一定会好起来的
S: 谢谢！希望可以帮忙转发扩散下, 谢谢了!
(S: For all the kind people, could you help me with my father's disease?)
(H: Cheer up! Your dad will get better for sure.)
(S: Thanks. Hope you could transmit and spread this message. Thank you.) 
In the above example, the speaker was trying to seek help and donation from strangers (hăoxīnrén: kindhearted people in English) in the chat group for his father's severe disease by asking a question with the conventional Chinese linguistic device (néng ... ma?, néng concerns the hearer's ability and "ma" is a Chinese modal particle to show uncertainty). The conventionally polite linguistic form reduces the imposition of request on the negative face of the hearer.

\subsubsection{Minimize the Imposition}

Brown and Levinson (1987) defined the degree of imposition as "a culturally and situationally defined ranking of impositions by the degree to which they are considered to interfere with an agent's wants of self-determination or of approval (negative and positive face wants)" (p. 77). Holtgraves \& Yang (1992) demonstrated a clear and positive relationship between the degree of imposition and overall politeness of language used.

Example7 The hearer is describing his life as overseas student in South Korea by posting many yet upsidedown pictures)

S: 直播吗？话说把照片放正了看可以嘛?

$\mathrm{H}$ ：哦哦，算是直播。我下次注意哈

(S: Live telecast ${ }^{1}$ ? I say, put the pictures right, please?)

(H: Yep, yep, this is sort of, live telecast. I'll be more careful next time.)

In Example 7, the speaker was a bit annoyed looking through all the topsy-turvy pictures presented by the hearer and thus requesting the hearer to upload the right pictures. By utilizing both hedge (huàshuō: I say), and question (Chinese modal particle "ma" to form a question), the speaker reduced the negative face threat to the hearer who accepted the request and promised to avoid doing that next time.

\subsubsection{Show Deference}

According to Scollon \& Scollon (1983), deference is in line with negative face and doing deference is a politeness strategy commonly adopted by interlocutors with asymmetrical power relationships. Usually people with relative lower power status are significantly more polite, showing deference for the face of the higher status person.

\section{Example 8 S: 跪求大神帮忙给公司起个名字！！ \\ $\mathrm{H}$ : 贵重金属公司。 \\ (S: Kneel to beg every master to help me name my company!!) \\ (H: Name it "Precious Metals".)}

In Example 8, the speaker was asking members of the chat group for help in naming his company. He used the word signaling the human posture (guì: kneel) which in Chinese culture is an action representing extreme respect and obedience to superordinates and also the address term dàshén ("saints or deity" in English) meaning experts in certain aspect in Chinese cyber language. By doing this the speaker put himself in a low power position to reduce the negative face threat to the hearer and realizing the intended communicative effects of obtaining help from others.

\subsubsection{Be Pessimistic}

In order to redress the negative face threat to the hearer, the speaker may convey doubts that the conditions apply for are imposing on the hearer by being pessimistic.

Example 9 S: 我只是个普通做咨询的, 从业多年, 如果你愿意, 我们可以聊聊。 $\mathrm{H}$ : 最近感觉很焦虑, 还有些抑郁, 情绪低落, 感觉很不好, 有什么好建议吗?

(S: I'm just an ordinary consultant working for many years. If you would like to, we could talk.)

(H: I've been very anxious recently and somehow depressed and gloomy. I feel very bad. Do you have any suggestions?)

${ }^{1}$ Live telecast in Chinese cyber language means someone is telling his story online extemporaneously. 
In the above example the speaker intended to offer help to the members of the chat group about their psychological problems. He first asserted his professional identity as an ordinary consultant (Wǒ zhǐshì gè pǔtōng zuò zixún de, "I'm just an ordinary consultant") and then asked whether the hearer wanted to talk with him about his troubles. By being pessimistic or modest (Gu, 1992) about his expertise he tried to lower his power and authority over the hearer and reduce the negative face threat to the hearer.

\title{
4.2.5. State the General Rule
}

By being phrased as a general rule or norm that applies to all people in general, the statement can be made more indirect or polite. This strategy avoids referring to pronouns such as "I" or "you" directly, i.e., impersonalizing the speaker and hearer which is a skillful social option as regards face threat.

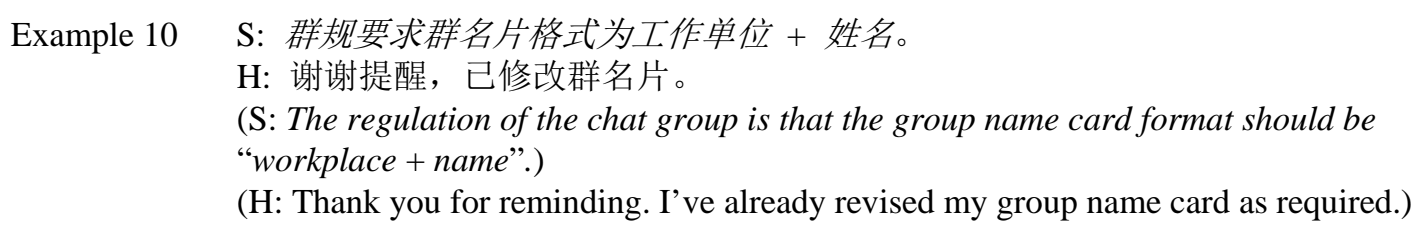

Example $10 \mathrm{~S}$ : 群规要求群名片格式为工作单位 + 姓名。

$\mathrm{H}$ : 谢谢提醒, 已修改群名片。

(S: The regulation of the chat group is that the group name card format should be "workplace + name".)

(H: Thank you for reminding. I’ve already revised my group name card as required.)

In the above example, the speaker as the moderator of the chat group was reminding one member that his group name card does not conform to the regulation. Instead of requesting the hearer to change his name card directly the speaker declared the regulation applicable to every member. Here the avoidance of the pronoun indexical annuls its directivity and thus saving the negative face of the hearer.

\subsection{Bald-on Record Strategies}

Bald-on record strategies usually do not attempt to minimize the threat to the hearer's face although there are ways that bald-on record strategy can be adopted in trying to minimize face-threatening acts implicitly. It is used when someone expresses something directly, clearly and unambiguously, so using such a strategy will often shock or embarrass the addressee. In IRC communication the interlocutors are anonymous and live in relatively physical safety which makes them less aware of their improper behavior or sometimes even choose not to redress or minimize the face threat.

\subsubsection{Do Not Minimize Face Threat}

According to Farall (2012), anonymous discussion provides a more freely environment to express something. The interlocutors may be impolite by adopting direct speech acts since no identifying information about them is present in IRC communication.

\author{
Example 11 S: 大家选择女朋友最看重什么? \\ $\mathrm{H}$ : 身材性格颜值人品。 \\ $\mathrm{S}$ : 要求不少 \\ $\mathrm{H}$ : 所以单着 \\ S: 活该单身狗 \\ (S: What do you think the most important in choosing a girlfriend?) \\ (H: Statue, personality, looks and character.) \\ (S: You are demanding.) \\ (H: That's why I'm still single now.) \\ (S: You deserve it, single dog.)
}

In Example 11, the speaker enquired about the merits that the hearer valued most when choosing their girlfriends. After the hearer gave his list of criteria for a good girlfriend, the speaker blamed him as too demanding (Yāoqiú bùshăo, "You are demanding”.) and eventually labelled him as dānshēngǒu ("single dog") which is a slightly derogatory term in Chinese internet culture. In this example, the speaker was being impolite by with the unmitigated speech act of criticism of someone he did not know without any desire to redress his face need due to the protection of identification information of IRC chat group members. 


\subsubsection{Minimize Face Threat Implicitly}

In IRC communication when the interlocutors discuss and exchange ideas or providing help and support, they may sometimes minimize face threat implicitly if the benefit brought by conducting the FTA outweighs the cost to their face want.

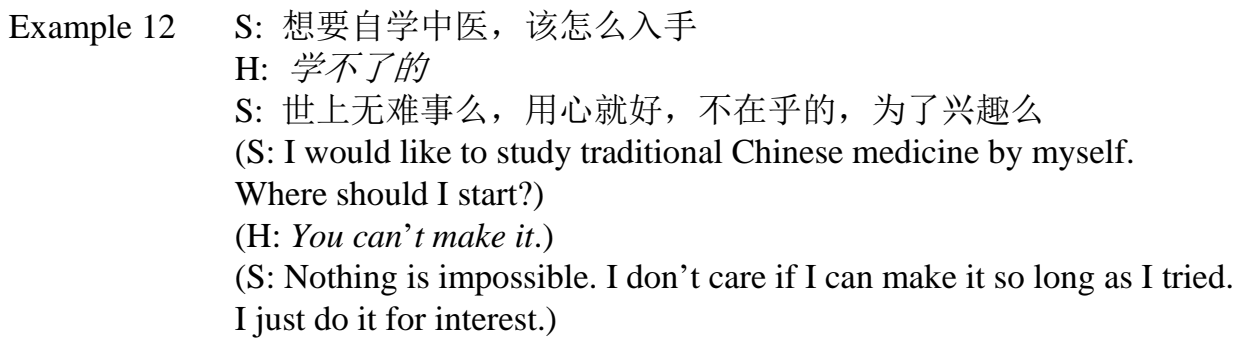

In Example 12, the speaker conveyed his wish to study traditional Chinese medicine by himself and asked for other members' opinion on it. The hearer blatantly stated that it was impossible to study traditional Chinese medicine (Xué bù liao de. "You can’t make it".) because it is a profound and complicated discipline for one to grasp by themselves. In this example the hearer minimized the face threat implicitly since he was trying to help by providing useful suggestions in the interest of the speaker so as to prevent the speaker's probably foolhardy attempts.

\subsection{Off-Record Strategies}

The final politeness strategy outlined by Brown and Levinson is the indirect off-record strategies which are in general more polite than on-record ones (Brown \& Levinson, 1987: p. 20). This strategy uses indirect language and removes the speaker from the potential to be imposing.

\section{Example 13 S: 爱读书的男生都在哪里 \\ $\mathrm{H}$ : 交个书友吗 \\ S: 我看的书可少了。你会嫌弃我 \\ (S: Where are all the book-loving boys?) \\ (H: Would you like to make friends with me?) \\ (S: I read rather few books. You would detest me.)}

In the above example, a girl asked the whereabouts of boys who like reading to share their thoughts about their favorite books, yet the hearer deliberately chose to ignore her intention and flirted her by proposing to make friends with her. Then the speaker went on to decline his request by the indirect speech act of stating herself as someone who read few books (wǒ kànde shū kě shăo le, "I read rather few books".) and would be distained by the hearer (Nǐ huì xiánqì wǒ, "You would detest me".). With the indirect speech act of assertive the speaker softened the positive face threat of refusal to the hearer.

\section{Conclusion}

Internet relay chat is a prevalent synchronous many-to-many mode of CMC communication in today's China. This study draws upon Brown and Levinson's face theory to analyze the politeness strategies frequently employed in public Chinese QQ chat groups which include positive politeness strategy, negative politeness strategy, bald-on-record and off-record strategy. The study contributes to the better understanding of the affordance of politeness and interpersonal relationship formation and maintenance in anonymous and public CMC context of non-western language and culture. However, this study is just a qualitative research of the typical politeness strategies in Chinese public IRC communication. More empirical studies on the deployment of these strategies would be conducive to the further exploration of politeness in CMC communication.

\section{Acknowledgements}

This study was funded by the Fundamental Research Funds for the Central Universities of The People's Repub- 
lic of China (Project nos. 30915013113 and NJUSTWGY14001).

\section{References}

Al-Shalawi, H. G. (2001). Politeness Strategies in Saudi ESL Computer-Mediated Communication. Dissertation Abstracts International, 61, 3969B.

Blum-Kulka, S. (1989). Playing it Safe: The Role of Conventionality in Indirectness. In S. Blum-Kulka, J. House, \& G. Kasper (Eds.), Cross-cultural Pragmatics: Requests and Apologies (pp. 37-70). Norwood: Ablex Publishing.

Brown, P., \& Levinson, S. (1987). Politeness: Some Universals in Language Usage. Cambridge: Cambridge University Press.

Clark, H. H. (1992). Arenas of Language Use. Chicago: University of Chicago Press.

Crystal, D. (2006). Language and the Internet (2th ed.). Cambridge: Cambridge University Press. http://dx.doi.org/10.1017/CBO9780511487002

Ervin-Tripp, S. (1972). Sociolinguistic Rules: Alteration and Co-Occurrence. In: J. Gumperez, \& D. Hymes (Eds.), Directions in Sociolinguistics (pp. 213-250). Cambridge: Basil Blackwell.

Farall, K. (2012). Online Collectivism, Individualism, and Anonymity in East Asia. Cyber-Surveillance in Everyday Life, 9 , 424-440.

Goffman, E. (1967). Interaction Ritual: Essays on Face-to-Face Behavior. Garden City, NY: Anchor Books.

Gu, Y. (1992). Politeness, Pragmatics and Culture. Foreign Language Teaching and Research, 4, 2.

Herring, S. C. (2010). Computer-Mediated Conversation: Introduction and Overview. Language@Internet, 7, Article 2. http://www.languageatinternet.org/articles/2010/2801

Hiemstra, G. (1982). Teleconferencing, Concern for Face, and Organizational Culture. In M. Burgoon (Ed.), Communication Yearbook (pp. 874-904). Sage: Newbury Park, CA.

Holtgraves, T., \& Yang, J. (1992). Interpersonal Underpinnings of Request Strategies: General Principles and Differences Due to Culture and Gender. Journal of Personality and Social Psychology, 62, 246-256. http://dx.doi.org/10.1037/0022-3514.62.2.246

Joos, M. (1962). The Five Clocks. New York: Harcourt Brace.

Lakoff, R. (1973). The Logic of Politeness, or Minding Your P’s and Q’s. Chicago Linguistics Society, 9, $292-305$.

Leech, G. N. (1983). Principles of Pragmatics. London: Longman.

Lorenzo-Dus, N., Blitvich, P., \& Bou-Franch, P. (2011). On-Line Polylogues and Impoliteness: The Case of Postings Sent in Response to the Obama Reggaeton YouTube Video. Journal of Pragmatics, 43, 2578-2593. http://dx.doi.org/10.1016/j.pragma.2011.03.005

Morand, D. A., \& Ocker, R. J. (2003). Politeness Theory and Computer-Mediated Communication: A Sociolinguistic Approach to Analyzing Relational Messages. Proceedings of the 36th Hawaii International Conference on System Sciences (HICSS-36), 6-9 January 2003. http://dx.doi.org/10.1109/hicss.2003.1173660

Pariera, K. (2006). The Use of Politeness Strategies in Email Discussions about Taboo Topics. PSU McNair Scholars Online Journal, 2, Article 29. http://dx.doi.org/10.15760/mcnair.2006.320

Park, J. R. (2008). Linguistic Politeness and Facework in Computer-mediated Communication. Journal of the American Society for Information Science and Technology, 59, 2051-2059. http://dx.doi.org/10.1002/asi.20916

Rheingold, H. (1993). The Virtual Community: Finding Connection in a Computerized World. Chicago, IL: Addison-Wesley Longman Publishing Co., Inc.

Scollon, R., \& Scollon, S. B. K. (1983). Face in Interethnic Communication. In J. C. Richards, \& R. W. Schmidt (Eds.), Language and Communication (pp. 156-188). London, United Kingdom: Longman.

Shea, V. (1994). Netiquette. San Francisco, CA: Albion Books.

Stalnaker, R. C. (1978). Assertions. In P. Cole (Ed.), Syntax and Semantics 9: Pragmatics (pp. 315-332). New York: Academic Press.

Taleghani-Nikazm, C. (2013). Politeness in Computer-Mediated Communication. The Encyclopedia of Applied Linguistics.

Tanskanen, S. (1998). Discourse in Cyberspace: Studying Computer-mediated Communication. Anglicana Turkuensia, 16, 143-156.

Yule, G. (2002). Pragmatics. Oxford: Oxford University Press. 


\section{Submit or recommend next manuscript to SCIRP and we will provide best service for you:}

Accepting pre-submission inquiries through Email, Facebook, LinkedIn, Twitter, etc.

A wide selection of journals (inclusive of 9 subjects, more than 200 journals)

Providing 24-hour high-quality service

User-friendly online submission system

Fair and swift peer-review system

Efficient typesetting and proofreading procedure

Display of the result of downloads and visits, as well as the number of cited articles

Maximum dissemination of your research work

Submit your manuscript at: http://papersubmission.scirp.org/ 